\title{
Leonard's Price Index of Latin American Art at Auction
}

\section{Susan Theran}

Auction

Index, Inc.

Newton, Massachusetts 
Important Notice: The artists' prices in this price guide are based on the Auction Index, Inc. database. All information, including valuations, has been compiled from the most reliable sources, and every effort has been made to eliminate errors and questionable data. Nevertheless, the possibility of error in a work of such scope always exists. Neither the editor nor the publisher will be held responsible for losses that may occur in the purchase, sale, or other transaction of items because of information contained herein. Readers who feel they have discovered errors are invited to write the editor in care of Auction Index, so the errors may be corrected in subsequent editions.

ISBN 978-1-349-15086-1 ISBN 978-1-349-15084-7 (eBook)
DOI 10.1007/978-1-349-15084-7

Susan Theran: Editor \& Publisher

Margaret McDonald: Chief Research Editor

Paula Jacoff: Editor

Design Studio: To The Point

Art History Consultant: Dr. Norma Steinberg

Published in 1999 by

Auction Index, Inc.

30 Valentine Park

Newton, Massachusetts 02465

(617) 964-2876 FAX (617) 969-9912

\section{END PAPERS}

Tomás Sánchez Antes de la tormenta

Christie's New York Latin American sale November 24, 1997

Library of Congress Catalog Card Number: $98-94934$

Leonard's Price Index of Latin American Art at Auction

Copyright (C 1999 Palgrave Macmillan, a division of Macmillan Publishers Limited

Originally published by Auction Index, Inc. in 1999

Softcover reprint of the hardcover 1st edition 1999 978-0-333-92104-3

All rights reserved under international copyright conventions.

No part of this book may be reproduced or utilized in any form or by any means (electronic, mechanical, photocopying, recording, or by any information storage or retrieval system) or transmitted in any form (including CD-ROM or via the Internet) or by any means without the written permission of the publisher. 


\section{Acknowledgments}

Many thanks are due to my colleagues and friends who have helped this book come into being...

A special thank-you to Peggy McDonald for her tireless and creative research from locating the name of the hacienda where Simon Bolívar died to finding the meaning (via the Web) of the pseudonym Nahui Olin.

A very special thank you also to my friend Dr. Norma Steinberg for her expertise and for being my most valuable sounding board.

Janet Bemis and Gia S. Jobin, of To The Point designers, are due special kudos for their expertise and patience in helping to bring this book into its final form.

and, thank you:

to the art experts who contributed articles for this book: Alejandro Anreus, Mary-Anne Martin, and August Uribe.

to the many libraries and museums throughout the country who provided their services and information. A special thank you to the hard-working and everhelpful staff at the Boston Public Library's art reference department - Janice Chadbourne, Kim Tenney, Evelyn Lannon, and Cecile Gardner; to Judy Baran at the Miami Public Library's art reference department; and to Elinor Hernon of the Newton Public Library for her resourceful help in procuring obscure citations.

to my staff who worked so tirelessly entering the auction data, compiling the research data, and proofing, over and over again, the proper spelling of names and geographical sites: Peggy McDonald, Paula Jacoff, Keith Larson, and Matthew McDonald.

to my daughters Sally and Rachel for their loving support.

\section{Auction House Acknowledgments}

Special appreciation and thanks to the many auction houses who provide catalogs and prices in a timely manner for the Auction Index database. The names and addresses of all these houses are listed in Appendix B.

A special thank you also to all the auction houses that so generously provided the photographs and some of the stories behind the captions. They are: James R. Bakker Galleries, Butterfield's, Christie's New York, Dawson's Auction Galleries, Doyle Galleries, Gary Nader Galleries, Hart Galleries, Arthur James Galleries, John Moran Auctioneers, Selkirk's, Skinner's, Sloan's Miami, Sloan's Washington D.C., Sotheby's Los Angeles, Sotheby's New York, Weschler's Auctioneers, William Bunch Auctions, and Wolf's Auctioneers. 


\section{Table of Contents}

From the Publisher

Susan Theran

Essays

The Latin American Auction Market 3

Mary-Anne Martin

Twentieth Century Art of Latin America

Alejandro Anreus

Latin American Art

August Uribe

How to Use this Book

Auction House Terminology

Abbreviations

How to Read an Entry

Artists' Biographies

Auction Prices

\section{Appendices}

Appendix A: Nationality Index

Appendix B: Auction House Addresses

520

Appendix C: Institutions Specializing

524

in Latin American Art

Appendix D: Sale Dates Cited

525

Appendix E: Indexing Guidelines

531

Appendix F: Auction Vocabulary 